\title{
O paraíso não é aqui: a violência contra a mulher em Tatiana Salem Levy
} Paula Queiroz Dutra ${ }^{1}$

Our silence will not protect us Audre Lorde

A violência contra a mulher é considerada hoje um problema de saúde pública global. De acordo com o relatório de status global na prevenção da violência de 2014, publicado pela Organização Mundial de Saúde, uma em cada cinco mulheres relataram ter sido abusadas sexualmente na infância, e uma em cada três mulheres foram vítimas de violência sexual ou física por parceiro íntimo em determinado momento de suas vidas (WHO, 2014). Apesar dos programas e iniciativas de prevenção por parte de governos e instituições em todo o mundo, ainda há muito a ser feito para acabar com a desigualdade e a consequente violência de gênero.

Do ponto de vista da literatura, a mesma preocupação que tem motivado mais estudos e ações governamentais visando o fim da violência contra a mulher parece também motivar autores contemporâneos a escrever sobre o tema. Ainda que cientes de que a literatura não tem o poder de reestabelecer a ordem do mundo e corrigir suas desigualdades, não podemos nos esquecer de seu poder de denúncia, assim como de sua capacidade de promover reflexões sobre questões importantes de nosso cotidiano e, consequentemente, de ser o primeiro passo para a conscientização rumo a uma mudança.

Na literatura brasileira contemporânea, o recém-publicado romance da escritora Tatiana Salem Levy ${ }^{2}$ traz para a cena literária brasileira, pela perspectiva feminina, as várias formas de violência a que as mulheres estão sujeitas, o que justifica a escolha deste romance para a análise que faremos a seguir. Em um cenário ainda alarmante de violência, em que

\footnotetext{
${ }^{1}$ Doutoranda em literatura na Universidade de Brasília (UnB), Brasília, DF, Brasil. E-mail: qpaulad@gmail.com

2 Não é a primeira vez que a questão da violência contra a mulher aparece na obra de Tatiana Salem Levy. Em A chave de casa (2007), seu premiado romance de estreia, a autora aborda, entre outros assuntos, a violência por parceiro íntimo em uma relação abusiva e o consequente trauma em uma das personagens. Já Dois rios (2011), seu segundo romance, não versa sobre o tema em foco nesse artigo, a violência contra a mulher.
} 
muitas vezes a violência contra a mulher é banalizada e negligenciada como alguns estudos apontam, é importante que uma reflexão sobre o tema seja estimulada.

Por ser recente, o romance tem por fortuna crítica apenas algumas resenhas e entrevistas com a autora, disponíveis nos principais meios de comunicação do país, como os jornais O Globo, Estadão, Folha de S. Paulo e a Globo News, para citar alguns. A crítica, no entanto, tem se divido entre criticar o romance e elogiá-lo, seja por considerar o assunto abordado um tema previsível, seja por reconhecer no romance alguns dos elementos que consagraram a autora como um dos destaques da chamada nova geração de escritores brasileiros. A temática da violência contra a mulher, no entanto, tem sido pouco explorada nas resenhas sobre o livro, o que também merece ser problematizado.

Este artigo, portanto, tem por objetivo analisar a representação da violência contra a mulher no romance Paraíso (2014), buscando compreender e problematizar a representação da dor do outro, do posicionamento das mulheres diante de situações de violência, e a crítica que é feita a essa violência nesse romance de autoria feminina.

\section{Aporte teórico e metodológico}

No ensaio "A crítica feminista no território selvagem", de 1981, Elaine Showalter (1994) faz uma reflexão sobre a crítica literária feminista no cenário teórico que, tanto na tradição literária americana como na tradição literária de modo geral, tem sido um domínio exclusivamente masculino. O pioneirismo das críticas feministas em contestar esse espaço e suas regras demonstrou a necessidade do movimento feminista de marcar presença também no âmbito da teoria. As diversas metodologias e ideologias que se denominam leitura ou escrita feminista refletem a própria diversidade do movimento feminista que, por isso, buscou evitar a tendência de se limitar ou colocar fronteiras em suas iniciativas. Enquanto a crítica científica sempre lutou para se afastar do que é subjetivo, a crítica feminista reafirmou a autoridade da experiência. Nesse sentido, a crítica feminista celebrou o distanciamento das metodologias tradicionais (e patriarcais) como forma de resistência e de confrontar o cânone existente, sendo caracterizada por uma recusa à codificação e ao estabelecimento prematuro de seus parâmetros. 
Concordando com teóricas como Annette Kolodny (1985), que defende o pluralismo da teoria crítica feminista como única posição compatível com o presente status do movimento de mulheres como um todo e que compara esse posicionamento crítico a dançar em um campo minado, Showalter defende o pluralismo como posição, mas ressalta que não é possível excluir um possível consenso teórico. A autora aponta a necessidade de uma crítica que seja genuinamente centrada na mulher, independente e intelectualmente coerente, que desenvolva sua própria teoria e encontre sua própria voz.

Ao longo do tempo, a crítica feminista mudou gradualmente seu foco das leituras revisionistas para uma investigação consistente da literatura feita por mulheres, o que redefiniu o seu problema teórico. A questão principal a ser discutida passou a ser a diferença nos escritos das mulheres, e esse novo período da história e crítica literária feministas passou a questionar como a condição mesma da mulher moldou a expressão criativa feminina. Com isso, buscou-se reafirmar o valor do feminino e identificar o projeto da crítica literária feminista como a análise da diferença, tentando resgatar o feminino de sua associação ao inferior, ao subalterno.

Mais que definir uma única diferença na escrita das mulheres, Showalter destaca que é através da investigação da literatura escrita por mulheres que podemos aprender mais sobre a relação da mulher com a cultura literária, assim como as ausências e exclusões que marcaram a história da escrita das mulheres.

Baseando-se no modelo cultural que interpreta a produção literária das mulheres em relação a seus contextos sociais, Showalter defende a adoção desse modelo, pois:

uma teoria cultural reconhece a existência de importantes diferenças entre as mulheres como escritoras: classe, raça, nacionalidade e história são determinantes literários tão significativos quanto gênero. Não obstante, a cultura das mulheres forma uma experiência coletiva dentro do todo cultural, uma experiência que liga as escritoras umas às outras no tempo e no espaço (Showalter, 1994, p. 44).

Aqui, a autora apresenta um tópico que será aprofundado por Iris Young, cujo conceito de serialidade será discutido mais adiante, o de que a identidade feminina não repousa apenas no gênero, mas também em outros indicadores, como idade, classe, etnia etc. 
Assim, o assunto essencial da crítica literária feminista passa a ser o conhecimento dos textos das mulheres, e o papel que essa produção ocupa na história e na tradição crítica. Afinal, é papel da crítica feminista "ver significado no que previamente havia sido espaço vazio" (Showalter, 1994, p. 53), sem esquecer que "a escrita das mulheres é um "discurso de duas vozes", que personifica sempre as heranças social, literária e cultural, tanto do silenciado quanto do dominante" (Showalter, 1994, p. 50). Dessa forma, Showalter evidencia a importância de compreender a diferença da escrita das mulheres, do que elas realmente escrevem e não de um ideal do que deveriam escrever, dentro dessa relação cultural complexa e historicamente fundamentada.

Usaremos como metodologia de análise o close reading (Eagleton, 2006, p. 67), abordagem que insiste na atenção devida ao texto, por meio de uma detalhada interpretação analítica e sugere uma atenção para aspectos específicos, deixando implícito que há uma direção de preocupação que norteia a análise - no nosso caso, a representação da violência contra a mulher, sob o viés dos estudos de gênero.

\section{Análise do corpus}

Em Paraíso, Tatiana Salem Levy nos apresenta Ana, a protagonista e narradora do romance, que se vê diante de um impasse quando, no dia seguinte a uma noite de bebedeira e irresponsabilidade, recebe a notícia de que o homem com quem acabou de ter relações sexuais sem proteção tem aids. Em pânico diante da possibilidade de ter sido contaminada, Ana começa a fazer um tratamento agressivo com medicamentos, mas só terá a confirmação que eliminará qualquer suspeita de contágio após o terceiro exame, a ser realizado um mês depois. É nesse mês de espera e de angústia que se passa o romance, o que evidencia a tese de Paul Ricoeur (2010, p. 93) de que é a narrativa que torna acessível a experiência humana do tempo.

Ao longo da história, percebe-se que "o medo de Ana não era apenas estar doente. Era também o medo do passado" (Levy, 2015, p. 11). Um passado que retorna cheio de força, evidenciando o papel da memória na construção do enredo.

A reflexão sobre o tempo e a atividade de narrar histórias, desenvolvida por Paul Ricoeur em Tempo e narrativa, com base na 
aproximação teórica das Confissões, de Santo Agostinho, e da Poética, de Aristóteles, tem como tese permanente o fato de que a narrativa é a única resposta possível para qualquer especulação sobre o tempo, ainda que não apresente uma solução para a aporia resultante de uma tentativa de definição. Compreendemos o tempo na medida em que podemos medi-lo como tempo passado (compreendido como memória) ou tempo futuro (compreendido como expectativa), e isso é feito por meio da linguagem. Porém, diante da dificuldade de se medir e localizar no espaço o tempo presente, Ricoeur aponta como solução a ideia do triplo presente, ou presente distendido:

Confiando à memória o destino das coisas passadas e à expectativa o das coisas futuras, pode-se incluir memória e expectativa num presente ampliado e dialetizado, que não é nenhum dos termos anteriormente rejeitados: nem o passado, nem o futuro, nem o presente pontual, nem mesmo a passagem do presente (Ricoeur, 2010, p. 23).

No romance, o deslocamento constante entre a expectativa de Ana em relação ao futuro e as suas memórias de eventos passados configuram o tempo da narrativa, pois segundo Ricoeur "o que medimos não são as coisas futuras ou passadas, mas sua expectativa e sua lembrança" (2010, p. 38). Esse deslocamento entre futuro (expectativas) e passado (memória) compõe a ideia de triplo presente ou presente distendido, um presente que se recompõe a partir de uma memória que se refaz. Mesmo lutando para esquecer certos eventos traumáticos que marcaram sua vida, a narradora Ana recupera no presente, por meio do que Ricoeur chama de imagens-vestígio, o seu passado. São as obras de linguagem, no caso a narrativa escrita por Ana no romance metaficcional, que mediam um ponto de partida e um ponto de chegada, uma configuração de mundo e outra.

A partir dessa reflexão inicial sobre o tempo, Ricoeur formula uma noção de mímesis baseada em três momentos para explicar a transformação de um elemento do mundo real em um texto literário, para comprovar a sua hipótese de que existe uma correlação entre a atividade de narrar uma história e o caráter temporal da experiência humana. Esse processo mimético é dividido em três etapas: a mímesis I, a mímesis II e a mímesis III. A mímesis I ocorre na subjetividade do autor e é a précompreensão do mundo da ação que delineia a construção da intriga. A mímesis II é a mediação entre o antes e o depois da configuração, ou seja, se dá na reconfiguração de um elemento do mundo real em texto 
narrativo, podendo ser compreendida como a própria intriga e agenciamento da ação. A mímesis III ocorre no ato da leitura, evidenciando o papel do leitor nesse processo, pois "o texto só se torna obra na interação entre texto e receptor" (Ricoeur, 2010, p. 132), ou seja, é no leitor que termina o percurso da mímesis.

Tendo como princípio norteador para pensarmos a representação literária a tríplice mímesis formulada por Ricoeur, assim como a ideia de que "as obras literárias também trazem para a linguagem uma experiência e assim vêm ao mundo como qualquer discurso" (Ricoeur, 2010, p. 134), buscaremos analisar a violência contra a mulher representada no romance, em suas variadas formas.

\section{A violência étnica}

Patricia Waugh (1989) define como metaficcional a escrita de ficção que conscientemente chama a atenção do leitor para seu status de artifício, de construção, com a intenção de problematizar a relação entre ficção e realidade.

Ao fazer uma crítica aos seus próprios métodos de construção, tais obras não apenas examinam as estruturas fundamentais da narrativa de ficção, mas também exploram a ficcionalidade possível do mundo fora do texto literário (Waugh, 1989, p. 2, tradução nossa).

Como romance metaficcional, Paraíso narra a história de uma escritora jovem durante o processo de elaboração de seu romance sobre uma maldição lançada por uma antiga escrava e sacerdotisa sobre as cinco subsequentes gerações de mulheres da família do barão de café da região. Por ser a última geração atingida por esta maldição, Ana decide contar a história da escrava, cujo nome desconhecemos, para tentar quebrar o feitiço e, com isso, ter alguma possibilidade de ser feliz no amor.

Para Ana, a escrita é uma forma de ressignificar a dor e seu sofrimento: "como se a dor pudesse simplesmente se deslocar do corpo para o papel, mas logo descobrira que bastava um detalhe sair do lugar, uma pequena angústia, para voltar a sofrer" (Levy, 2015, p. 12). A memória tem um papel importante na narrativa e Ana "vivia fugindo da memória, certa de que a felicidade exigia o esquecimento" (Levy, 2015, p. 12). As lembranças que perseguem a protagonista ressurgem fortalecidas, desencadeadas pela angústia diante da espera pelo resultado do exame. 
Ao decidir escrever a história da escrava na fazenda de café do século XIX, apesar de deslocar o cenário do âmbito urbano que prevalece na literatura brasileira contemporânea (Dalcastagnè, 2012) e, principalmente, na obra de Tatiana Salem Levy, a autora tenta dar voz ao outro, narrando a história da escrava, marcada pela violência étnica, em um relato que tem características de depoimento.

A narração em primeira pessoa da trajetória da escrava, uma princesa africana raptada em seu país e trazida de navio para o Brasil para servir na fazenda do barão de café, torna o outro o sujeito do discurso. Esse deslocamento da voz narrativa é positivo pela tentativa de dar voz a figuras marginalizadas e pouco exploradas na literatura brasileira, como a de uma escrava negra. Porém, é importante lembrar, aportando-se à observação de Janet Paterson, que:

Quando discutimos o outro, frequentemente focalizamos formas diferentes de alteridade como se elas estivessem separadas de nossa consciência e identidade. Entretanto, alteridade implica um processo cognitivo (e, muitas vezes, ideológico) que se manifesta dentro do sujeito e consequentemente dentro da sociedade. Visto que a alteridade está na raiz das guerras, do racismo e da discriminação, é imperativo que ela seja reconceitualizada (Paterson, 2007, p. 15).

Falar do outro é também falar de si, uma vez que é com base em nossas experiências e vivências que vemos o outro, julgando seu valor, sua diferença. Mas falar e representar a dor do outro é um desafio ainda maior, que merece uma consideração ética, como já apontado por Susan Sontag em Diante da dor dos outros (2011) ao comentar sobre as fotografias de guerra. Mesmo dando voz a essa escrava, por mais válido que seja o deslocamento da voz narrativa, a história continua a ser narrada a partir da perspectiva de uma jovem branca de classe média, que ocupa uma posição de prestígio (no sentido de ter acesso ao discurso por ser escritora).

No romance, o barão de café é retirado de qualquer individualidade, sendo sempre designado por sua posição social e seu status de poder. Já a escrava, apesar de também não ser nomeada, não é a mera projeção de uma posição social, ela tem uma história, que a individualiza no enredo.

Ao retratar o "relacionamento" entre o barão e a escrava de forma romantizada, a dor das escravas negras, cujos corpos foram apropriados pelos "donos de escravos" inúmeras vezes ao longo da história, foi minimizada e apagada quando transformada em história 
de amor. Do ponto de vista da violência contra a mulher, a descrição de um estupro como um fato que possa despertar amor ou até mesmo ternura, banaliza uma violência que é considerada "a forma mais evidente da dominação exercida, de maneira violenta, dos homens sobre as mulheres" (Ockrent, 2011, p. 207). Isso pode ser observado no trecho a seguir:

De longe, sentia-se seu cheiro acre, o mesmo que me afugentava e atraía. Ainda hoje, eu só saberia descrever meu sentimento pelo barão como uma mistura de amor e ódio. No início, era apenas raiva, por ele fazer comigo o que eu não queria, por me obrigar a me entregar do jeito que lhe apetecesse. Depois, foi também atração, e certa ternura. Até que Ayomide nasceu, e o amor se tornou maior do que o ódio (Levy, 2014, p. 78).

No entanto, ao fazer uso da metaficção para refletir sobre o próprio papel dessa narradora-escritora, Levy evidencia o dilema do escritor frente à alteridade, questionando seu direito e capacidade de falar da dor, de representar o sofrimento de alguém que ocupou um universo tão distante do seu, valorizando a experiência como potência propulsora da escrita.

Não tinha preparado o discurso, a ideia havia surgido vaga, e ela agora pensava em voz alta no que consistiria aquela nova trama. Talvez mudasse alguns detalhes, foi o que disse, mas um ponto era mesmo fundamental: não sabia inventar histórias. Nunca conseguiria levar a cabo o livro da escrava na fazenda de café, por um único motivo: não era uma escritora de grande imaginação. Tentava provar ser capaz de elaborar uma história fabulada, mas no fim o que a motivava era a própria experiência, as pessoas com quem cruzava, os lugares aonde ia. [...] Queria fazer um romance simples, enxuto, inventar o que ela mesma estava vivendo (Levy, 2014, p. 137-138).

Não podemos nos esquecer de que também é papel da literatura retratar as diferentes perspectivas sociais. Mas, como nos lembra Regina Dalcastagnè: "a representação não dispensa a necessidade da presença do outro, não elimina a exigência da democratização do fazer literário" (Dalcastagnè, 2012, p. 195), o que demonstra a importância de uma maior democratização no campo literário, para que mais escritoras negras possam contar suas histórias.

No romance, é o ciúme que a sinhá sente da escrava com o barão o motivo de sua ira. Então, ela ordena que a escrava seja enterrada viva em um momento em que o barão está ausente. Antes de ser enterrada, a 
escrava, que era uma importante sacerdotisa Gelede ${ }^{3}$ em seu país, lançalhe uma maldição: durante cinco gerações, as mulheres da família seriam infelizes no amor, pois "o poder da palavra dessas sacerdotisas era tão grande que mesmo os homens mais guerreiros o temiam" (Levy, 2014, p. 20). Assombrada pela voz dessa mulher condenada à morte, que na imaginação de Ana clama para que sua história seja contada, ela, a narradora-escritora, decide ir para o campo para se afastar do cotidiano da cidade e escrever o seu romance.

Conforme apontado por Adelaide Miranda em seu estudo sobre a memória e a cidade na narrativa brasileira de autoria feminina, "o esquecimento das personagens é seguido de uma preocupação com os atos de resgatar e recontar suas histórias" (Miranda, 2015, p. 86). Nesse caso, contar a história da escrava é também contar a história das mulheres da família, que tiveram um impacto direto na vida de Ana e na construção de sua própria história. É também acessar memórias guardadas que são refeitas através da narrativa.

Imaginou a fazenda de café e se recobrou da certeza de que precisava dar voz a quem fora silenciado. Embora fosse descendente da sinhá, não seria cúmplice da crueldade da mulher que obrigara outros escravos a enterrarem viva a amante do barão [...]. Ana acreditava que a violência da sua antepassada era o motor que explicava a fúria da sacerdotisa. De nada adiantaria repetir a história e continuar falando do mesmo lugar (Levy, 2014, p. 20-21).

Nos trechos acima, uma das passagens metaficcionais do romance, a narradora demonstra consciência do seu lugar de fala e da necessidade de dar voz àqueles que sempre foram silenciados, justificando, portanto, o deslocamento da voz narrativa em determinados momentos do texto para narrar, em primeira pessoa, a história da escrava. Ao mesmo tempo, ela se posiciona de forma contrária à violência, apesar de se reconhecer como "descendente da sinhá". Ainda assim, é importante observar, tendo por base o modelo cultural de crítica adotado por Showalter já mencionado, que não é possível refletir sobre a violência sem considerar, além do gênero, raça, classe social, sexualidade, e história.

\footnotetext{
${ }^{3}$ Geledés é originalmente uma forma de sociedade secreta feminina, de caráter religioso, existente nas tradicionais sociedades yorubás. Expressa o poder feminino sobre a fertilidade da terra, a procriação e o bem-estar da comunidade.
} 


\section{A violência doméstica: o casamento}

O problema da violência doméstica é explorado por Levy através da personagem Rosa, a empregada doméstica que trabalha no sítio de uma amiga, em local afastado da cidade e cercado pela natureza, onde a narradora Ana encontra o cenário ideal para escrever. Exceto por Carlos, o motorista, e Rosa, a empregada doméstica, Ana estava sozinha com seu medo e suas memórias no sítio ironicamente chamado Paraíso.

A ironia em torno da ideia de Paraíso, no entanto, desconstrói a imagem do casamento como o ideal de realização da mulher. Casada com Sérgio, Rosa abandona sua individualidade e se submete a várias formas de violência, por julgar que aquele era o destino que lhe cabia. Os ciclos de violência, comuns em relacionamentos abusivos, são representados no comportamento de Rosa que, inicialmente triste por ter sido abandonada pelo marido, depois o aceita de volta e sofre novamente com mais um episódio de agressões. O arrependimento de Sérgio e o senso de responsabilidade pela manutenção da família que ela possui - ainda que isso implique em sacrifícios, uma ideia que fundamenta muito da estrutura patriarcal - impedem que Rosa denuncie seu marido pelas agressões, levando-a a se calar diante da violência. A denúncia não é feita, mesmo com a insistência de Ana, e um novo episódio de violência volta a acontecer, de forma ainda mais trágica.

Se inicialmente a tristeza de Rosa parece não chamar a atenção de Ana, que continua concentrada em seu romance, após as marcas visíveis das agressões, a situação muda. Com isso, Levy demonstra como a violência contra a mulher é ainda mais naturalizada e invisibilizada nas camadas mais pobres da população, reforçando a importância de adotar o modelo cultural de crítica destacado por Elaine Showalter. Rosa permanece "invisível" em situação de subalternidade, exercendo seu trabalho de cuidar da casa e cozinhar. Mas quando a violência deixa marcas no corpo de Rosa, Ana percebe que nada sabe sobre a vida daquela pessoa que estava ali, tão próxima a ela, servindo-a diariamente desde que chegara ao sítio. Essa tomada de consciência da personagem a partir da alteridade provoca no leitor uma reflexão sobre a violência psicológica, que causa sofrimento de forma silenciosa a pessoas próximas, mas que parece só ficar visível quando atinge a forma de violência física.

O comportamento de Rosa, no entanto, evidencia os problemas existentes na sua relação com o marido, Sérgio. Descrita como uma 
personagem que abandona tudo, até mesmo sua crença, para ficar com Sérgio, Rosa encarna o estereótipo da mulher que tudo sacrifica pela família e pelo casamento. O casamento de sonhos com um homem religioso e respeitado na comunidade depois começa a dar sinais de fracasso, mas Rosa cumpre o papel de esposa que a sociedade lhe impõe e silencia os acontecimentos que ocorrem no âmbito doméstico. A diferença no comportamento de Sérgio quando na comunidade ou na própria casa demonstra como essa fronteira entre público e privado afeta diretamente as mulheres.

Demorou para Sérgio se tornar um homem em casa, outro na rua. Kelly já existia, mas era ainda uma menina que não aprendera a ler. Rosa tinha a sensação de que ele gastava todas as palavras na igreja, $\mathrm{e}$ para a família não sobrava nenhuma. Começou a beber, a fumar, enquanto ela escondia dos outros o que se passava dentro de casa. $\mathrm{O}$ pastor não podia descobrir que ele tinha se entregue ao álcool. Também não podia saber muitas outras coisas que Rosa guardava para si (Levy, 2014, p. 112).

Quando questionada por Ana sobre as marcas que carrega no corpo, Rosa nega que as agressões foram provocadas pelo marido e usa como desculpa ter levado um tombo no jardim. Seja por vergonha, seja por medo, ou mesmo pela ideia socialmente construída de que isso faz parte do casamento, Rosa silencia seu sofrimento. Inconformada com a situação, Ana tenta convencê-la de que é possível reagir.

Ana tentou ser didática, disse que milhares de mulheres são vítimas de violência doméstica, ela não era a única, e tinha que denunciá-lo. Então Rosa berrou não foi ele. Eu já disse pra senhora, caí ontem à noite. Sérgio é um homem bom (Levy, 2014, p. 122).

A recusa de Rosa em admitir o que de fato acontecia desperta em Ana um sentimento de indignação diante da violência que atinge todas as mulheres, independentemente de raça, idade, sexualidade, classe social. A raiva que ela sente não é apenas por Rosa, mas por ela mesma, pelas mulheres de sua família, todas personagens dessa história que traz figuras femininas no centro da trama.

Os roxos impressionavam pela intensidade. Nenhum tombo faria aquilo, era óbvio. Repousou o copo na pia e saiu, a passos muito lentos. No alpendre, sentiu a raiva crescer, não só pela evidência do acontecimento, mas também pelo que ela guardava consigo e agora subia pelo corpo, veloz, reativado. Uma raiva ancestral, por ela, pela mãe, pelas mulheres do romance (Levy, 2014, p. 121). 
Após a primeira tentativa de Ana de ajudar Rosa a sair do relacionamento violento em que se encontrava, Sérgio retorna demonstrando arrependimento, com flores e presentes para convencê-la de que as agressões não se repetiriam. Rosa retorna então ao ciclo de violência, conforme explicado por Schwab e Meireles: inicialmente há a fase da tensão, depois a fase da agressão, seguida da fase de desculpas e, por fim, a fase da reconciliação (Schwab e Meireles, 2014, p. 26). É esse ciclo que faz a mulher ser tolerante sem nem perceber, julgando que a agressão não se repetirá. Em uma conversa com Daniel, um artista recluso com quem começa a se relacionar, Ana demonstra como até mesmo para as pessoas próximas, a fase de desculpas e de reconciliação parece convencer e mascarar o problema.

Ana estava particularmente feliz e queria dizer que ele talvez tivesse razão, Sérgio chegara com flores e presentes na casa de Rosa. Embora ainda estivesse abalada com os fatos recentes, sentia-se mais aliviada. Conversara com Rosa por longos minutos, percebera segurança na sua voz. Ainda desconfiava, mas não estava certa de que Sérgio fosse o responsável pelas marcas no seu corpo. Sorte que a gente não foi à delegacia, afirmou. Você tinha razão, não temos nada a ver com a história deles (Levy, 2014, p. 134).

Quando Ana, incentivada por Daniel, afirma que eles não devem interferir no problema entre o casal Rosa e Sérgio, ainda que isso implique em violência doméstica, Levy problematiza a questão da violência contra a mulher e demonstra, através do próprio desenvolvimento da narrativa, a ideia geral, que por muitos anos legitimou o espaço doméstico como propriedade exclusiva do homem, do patriarca, ao qual deveria pertencer também à esposa. Como destaca Heleieth Saffioti, "a violência doméstica ocorre numa relação afetiva, cuja ruptura demanda, via de regra, intervenção externa" (Saffioti, 1999, p. 85). Além disso, é necessária uma rede de apoio para oferecer suporte não apenas jurídico, financeiro, mas também psicológico, às mulheres vítimas de violência.

Sua voz saiu com ímpeto, firme, Sérgio é meu marido, pai de minha filha, foi Deus quem escolheu, Ele que quis assim. E agradeço todos os dias a Ele - apontava o dedo para cima enquanto falava - porque eu amo o meu marido e amo a Kelly. Parou, respirou, engoliu o choro e, por último, antes de subir as escadas rumo à sua casa, perguntou com que cara eu ia dizer pra minha filha que o pai dela foi preso? (Levy, 2014, p. 123). 
O trecho acima, no qual Rosa volta para casa depois de ter se recusado a prestar queixa na delegacia por ter sido espancada pelo marido, demonstra como a violência é socialmente enraizada e construída e como os próprios papéis de gênero no sistema patriarcal contribuem para que as mulheres permaneçam em relações abusivas. Afinal, são ensinadas a sacrificar sua liberdade e seus desejos para manter, acima de tudo, o casamento e o funcionamento da família.

Contudo, é o desfecho trágico do romance, quando Rosa é esfaqueada pelo marido em sua própria casa, tendo a filha como testemunha, que contesta o discurso de submissão da mulher. $\mathrm{O}$ comportamento agressivo de Sérgio diante da própria filha demonstra que a preservação da integridade da família não era uma preocupação dele e com isso desconstrói-se o mito de que não se deve interferir nos casos de violência entre um casal. Ao dar a Rosa um final que poderia ter sido evitado, houvesse a queixa sido feita, Levy reitera através do exemplo a necessidade de não se calar diante de uma situação de violência.

\section{A violência doméstica: a infância/adolescência}

Estudos demonstram que é no ambiente familiar que mulheres e crianças estão mais sujeitas à violência. Violência cometida quase sempre por pessoas próximas, com as quais as vítimas estabeleciam contato e tinham até uma relação de confiança. É no espaço doméstico, portanto, que as mulheres e as crianças estão mais sujeitas à violência, seja ela física, sexual ou psicológica. Pelo fato de ser cometida por pessoas próximas, torna-se ainda mais difícil reconhecer essas situações como violência e, mais ainda, romper o silêncio necessário para denunciar os agressores.

Em Paraíso, a narradora do romance, quando não está escrevendo a história sobre a escrava, tem que lidar com a sua própria história e com suas lembranças, vestígios de acontecimentos que permanecem fixados em sua mente. Memórias silenciadas durante a adolescência quando Ana não consegue denunciar os assédios que, aos 17 anos, começou a sofrer do seu padrasto, Raul:

ela iria olhar bem fundo nos seus olhos e dizer mãe, ele tentou me agarrar, o seu marido tentou me agarrar, e é por isso que ele está me dando esse livro, entendeu? Você acha que ele é um bom padrasto, né? Mas na verdade ele é um filho da puta. Só isso. Um filho da puta. Mais nada. E por fim iria implorar se separa dele, mãe, manda ele 
embora daqui. Mas não fez nada disso, e durante o jantar só ficou repetindo para si mesma que era fraca, se perguntando como podia manter um pacto de silêncio com aquele homem asqueroso, por que tanto medo? (Levy, 2014, p. 61).

Ao representar essa violência, tão comum segundo as estatísticas, Levy demonstra como a violência pode acontecer com qualquer pessoa, independentemente de sua classe social, e ser perpetrada por pessoas próximas. A angústia de Ana diante do medo de contar para a mãe e ser desacreditada, ou até mesmo culpada pelas investidas cada vez maiores de seu padrasto, demonstra como ainda nos dias de hoje, em que o diálogo entre as famílias parece ser mais aberto, certos assuntos ainda são tabu, ainda são difíceis de conversar, o que só fortalece o agressor: "Raul havia percebido - na noite em que lhe oferecera o livro - que ela não diria nada, era medrosa demais para isso. Ou amava demais a mãe" (Levy, 2014, p. 63).

Além disso, tanto o arrependimento de nunca ter contado para a mãe antes de ela falecer quanto a reação da personagem anos depois, já na idade adulta, quando reencontra Raul em uma de suas viagens e finalmente consegue dizer a ele tudo o que precisava ser dito, demonstram a importância de finalmente "rasgar o silêncio" (Levy, 2014, p. 59).

Ao comentar sobre o poder da televisão de formar opiniões e fazer circular discursos, Alice Walker, no livro Overcoming Speechlessness (2010), demonstra como certos estereótipos são usados para justificar ou alimentar certas violências. No caso em questão, a literatura, assim como a TV, é espaço de circulação de ideologias e pode reforçar estereótipos que validam certos comportamentos e violências, principalmente contra a mulher, já que é muito comum encontrarmos descrições de violências sendo romantizadas por escritores, o que pode contribuir para a sua naturalização, ainda que a intenção seja de crítica. Por isso, é importante a realização de estudos que pensem as representações de violência na literatura, principalmente contra a mulher, visto que essas representações têm um impacto no contexto social em que são lidas.

A mímesis III, conforme formulada por Ricoeur (2010), no que tange à representação, é significativa nessa reflexão por adotar o ato de leitura como o momento interpretativo, tanto nas narrativas históricas quanto nas narrativas ficcionais. Nesse sentido, evidencia-se como a ambiguidade na representação de uma violência pode ser problemática.

Com a personagem Ana, Levy proporciona uma reflexão sobre esse silêncio e toda a angústia e sofrimento que ele pode causar, mas 
também sobre a força que se alcança quando se rompe o silêncio e se aprende que "nenhuma vitória era melhor do que a da palavra dita" (Levy, 2014, p. 154).

\section{A violência sexual}

Para abordar o tema delicado da violência sexual, a memória tem um papel importante no romance. Nos deslocamentos entre presente e passado, que se alternam no desenrolar da narrativa, corroborando a ideia de presente distendido apresentada por Ricoeur (2010), uma história já conhecida da protagonista sobre um assalto ocorrido com a mãe quando ela ainda era criança é recontada e reconfigura a relação entre as personagens.

Ana está no carro com a mãe indo para a casa de uma amiga quando pede à mãe que lhe conte uma velha história, ouvida tantas vezes na infância, sobre um assalto do qual a mãe sai ilesa e os criminosos são punidos. Uma história que Ana adorava contar aos amigos, algo que lhe assegurava conforto e segurança: a justiça havia sido feita, tudo acabara bem. Anos depois, nesse momento em que mãe e filha, esta já uma adolescente, estão juntas no carro, Marieta, mãe de Ana, decide lhe contar a verdadeira história, talvez verbalizando pela primeira vez o seu trauma. Dentro do próprio romance, é a narrativa que serve de ponte entre o "vivido" pela personagem e o narrado por ela. Também aqui a linguagem funciona como mediadora de dois momentos, um antes e um depois, um ponto de partida e um de chegada, intermediados pelo texto.

A representação do estupro na literatura é uma temática discutida por feministas (Thompson e Gunne, 2010) que se dividem entre duas opiniões: representar o estupro e correr o risco de reiterar a figura da vítima, ainda alimentando uma possível erotização desse sofrimento; ou omitir essa representação e, com isso, reforçar o silêncio diante da dor e do trauma. Segundo Thompson e Gunne (2010, p. 6), um dos objetivos da segunda onda do feminismo foi colocar em pauta a questão do estupro, visando sua erradicação. Para as autoras, hoje o que está em questão não é representar ou não o estupro, mas como fazer isso e com que finalidade.

No romance, ao ouvir a história da mãe, Ana sente raiva, pois "a violência podia ter acontecido com ela havia anos, mas estava acontecendo com Ana naquele instante" (Levy, 2014, p. 130). O choque que a violência verbalizada pode provocar é representado na reação de Ana, mas logo 
depois isso se transforma em compreensão pelo sofrimento vivido pela mãe e silenciado no ambiente familiar por tanto tempo:

Mas a mãe prosseguiu assim que cheguei em casa, lavei a boca com água sanitária, durante meses lavei a boca com água sanitária. E durante meses não consegui fazer sexo com o seu pai. Ana só pensava que tudo acontecera quando ela já existiu, tinha cinco anos, e não soubera de nada (Levy, 2014, p. 130).

A reação de Ana à narrativa materna da violência sofrida no passado, inicialmente se parece com a de Alice Walker (2010) ao ouvir os relatos das torturas e da violência sofrida por sobreviventes de guerra, ao afirmar: "Ao chegar em casa, adoeci com o peso dessa história" (Walker, 2010, p. 16, tradução nossa). De forma semelhante, Ana também carrega o peso da história contada pela mãe, mas depois constatamos - pelo próprio caráter metaficcional da narrativa - que esse peso foi ressignificado, transformando-se em narrativa:

Mas nunca conseguiu falar sobre isso, nunca conseguiu repetir as palavras que ouvira, nunca conseguiu dizer que sabia, nem mesmo escrever sobre o assunto Ana conseguiu (Levy, 2014, p. 131).

Ao narrar o silêncio de Marieta em relação ao trauma e o efeito que isso teve em sua relação com o marido e pai de Ana, Levy nos mostra a importância de falar da dor para superá-la, a importância da narrativa para reconfigurar os papéis sociais, pois ao contar o evento como ele ocorreu, Marieta se apropria de eventos traumáticos de seu passado e através da narrativa estabelece uma forma de agir no mundo. Retomando o pensamento de Ricoeur (2010, p. 13), são as narrativas que mediam determinada configuração de mundo ou outra, pois construímos o mundo por meio de ações e por meio de palavras.

\section{Conclusão}

Por contemplar no romance as várias formas de violência sofrida pelas mulheres, independentemente de qual seja sua idade, raça, classe social, sexualidade etc., Tatiana Salem Levy traz para a narrativa contemporânea uma questão fundamental e que precisa ser mais discutida, não apenas na literatura, mas na sociedade atual.

A escrava, Ana, Rosa e as demais mulheres que fazem parte desse enredo representam uma parcela das muitas mulheres que diariamente sofrem violência em suas diversas formas, em várias partes do mundo. 
Muitas delas ainda nem sequer figuram entre as estatísticas, dada a dificuldade de denunciar e falar sobre sua dor. As diferenças entre elas são muitas e buscar características comuns a essas mulheres ou à opressão e violência que sofrem seria um engano já que, como observado por Iris Young:

é um erro qualquer tentativa de isolar o gênero de identidades de raça, classe, idade, sexualidade, etnicidade etc. para desvendar os atributos, a experiência ou as opressões que as mulheres têm em comum (Young, 1997, p. 13).

No entanto, é fazendo uso do conceito de gênero como serialidade ${ }^{4}$ apresentado por Iris Young (1997) que buscamos nos posicionar diante da violência contra a mulher. Ao nos apoiarmos na ideia de coletivo ou grupo social "mulheres", a partir desse conceito, poderemos não necessariamente identificar os membros desse grupo por um conjunto comum de atributos, mas compreendê-las pelo que em suas existências tão diversas elas são diretamente afetadas, nesse caso, a violência de gênero.

A ironia do título do romance destaca que ainda não vivemos no paraíso da igualdade de gênero, em que a violência já não aterroriza a vida das mulheres. Ao mostrar que o paraíso ainda não é aqui, a autora abre espaço para uma discussão importante sobre a violência contra a mulher e sobre a necessidade de demonstrarmos que é possível combatêla e que o primeiro passo é quebrar o silêncio que nos aprisiona.

Ao reforçar a ideia de que é necessário romper o silêncio, mesmo sendo difícil falar de uma dor sobre a qual não é possível falar completamente, ${ }^{5}$ Alice Walker, no livro Overcoming speechlessness (2010), traz à tona a necessidade de pensarmos a violência contra a mulher visando a sua erradicação. É importante notar que a violência da história faz calar também aquele que a ouve, como ocorre com Walker,

\footnotetext{
${ }^{4}$ A partir das ideias de Sartre em Crítica da Razão Dialética, Iris Young (1997, p. 23-24) desenvolve o conceito de série para pensarmos gênero. Partindo da ideia de que todas as relações humanas devem ser compreendidas como a produção de uma ação, Young define série como coletivo ou grupo social cujos membros se unem passivamente em torno de uma ação ou objetivo, mantendo sua individualidade em relação aos resultados que a aproximação em torno dessa ação ou objetivo possa resultar. Em uma série, os indivíduos estão isolados em suas particularidades, mas não sozinhos. Os membros de uma série podem ter histórias, experiências ou identidades diferentes, mas, ainda que não se identifiquem uns com os outros, carregam o potencial de se organizar em série como um grupo para atingirem juntos determinado objetivo, que afetará cada um de formas diferentes.

${ }^{5}$ Nas palavras de Alice Walker (2010), unspeakable tragedy - ou tragédia para a qual não há palavras (tradução nossa).
} 
ao ouvir o relato de uma sobrevivente da mais brutal violência física e emocional sofrida durante a guerra. Mas, em seguida, essa história se faz contar, não apenas através da sobrevivente, quando finalmente consegue abrir espaço diante do trauma e narrar o que lhe é possível narrar dessa tragédia para a qual não há palavras, mas da própria escritora Alice Walker. Com isso, ressignificam-se a dor e o sofrimento, e o choque inicial da violência narrada e vivida pode ser catalisado como força para recontar essas histórias. A literatura, dessa forma, pode ser um dos caminhos, certamente não o único, não algo suficiente, mas mais uma possibilidade de ajudar as mulheres a romperem o silêncio.

\section{Referências}

DALCASTAGNÈ, Regina (2012). Literatura brasileira contemporânea: um território contestado. Vinhedo: Horizonte.

EAGLETON, Terry (2006). Teoria da literatura: uma introdução. São Paulo: Martins Fontes.

KOLODNY, Annette (1985). Dancing through the minefield: some observations on the Theory, Practice and Politics of a Feminist Literary Criticism. In: SHOWALTER, Elaine (Ed.). The new feminist criticism: essays on women, literature and theory. New York: Pantheon Books, p. 144-167.

LEVY, Tatiana Salem. Paraíso. São Paulo: Foz, 2015.

MIRANDA, Adelaide C. (2015) Memória e cidade na narrativa brasileira contemporânea de autoria feminina. In: DALCASTAGNÈ, Regina; LEAL, Virginia (Org.). Espaço e gênero na literatura brasileira contemporânea. Porto Alegre: Zouk, p. 85-115

OCKRENT, Christine (2011). O livro negro da condição das mulheres. Rio de Janeiro: Difel.

PATERSON, Janet M. (2007). Pensando o conceito de alteridade hoje. Aletria, Belo Horizonte, v. 16, p. 13-19, jul.-dez. Disponível em: <http://goo.gl/3V2ndP>. Acesso em: 8 jul. 2015.

RICOEUR, Paul (2010). Tempo e narrativa. Tomo 1. A intriga e a narrativa histórica. Tradução de Claudia Berliner. São Paulo: Martins Fontes.

SAFFIOTI, Heleieth I. B. (1999). Já se mete a colher em briga de marido e mulher. São Paulo em Perspectiva, São Paulo, v. 13, n. 4, out.-dez., p. 82-91. 
Disponível em: <http://www.scielo.br/pdf/spp/v13n4/v13n4a08.pdf>. Acesso em: 8 jul. 2015.

SCHWAB, Beatriz; MEIRELES, Wilza (2014). Um soco na alma: relatos e análises sobre violência psicológica. Brasília: Logos 3.

SHOWALTER, Elaine (1994). A crítica feminista no território selvagem. In: HOLLANDA, Heloísa Buarque de (Org.). Tendências e impasses: o feminismo como crítica da cultura. Tradução de Deise Amaral. Rio de Janeiro: Rocco, p. 23-57.

SONTAG, Susan (2003). Diante da dor dos outros. São Paulo: Companhia das Letras.

THOMPSON, Zöe; GUNNE, Sorcha (2010). Feminism without borders: the potentials and pitfalls of re-theorizing rape. In THOMPSON, Zöe; GUNNE, Sorcha. Feminism, literature and rape narratives: violence and violations. New York: Routledge, p. 1-22.

YOUNG, Iris (1997). Gender as seriality: thinking about women as a social collective. In: YOUNG, Iris. Intersecting voices: dilemmas of gender, political philosophy and policy. Princeton: Princeton University Press, p. 12-37.

WALKER, Alice (2010). Overcoming speechlessness. New York: Seven Stories.

WAUGH, Patricia (1984). Metafiction: the theory and practice of self-conscious fiction. London and New York: Routledge.

WHO - WORLD HEALTH ORGANIZATION (2014). The global status report on violence prevention 2014. Geneva: WHO. Disponível em: <http:/ /goo.gl/B0JDtA>. Acesso em: 11 jun. 2015.

Recebido em agosto de 2015.

Aprovado em dezembro de 2015.

\section{resumo/abstract/resumen}

\section{O paraíso não é aqui: a violência contra a mulher em Tatiana Salem Levy}

Paula Queiroz Dutra

Este trabalho tem por objetivo analisar as representações das diferentes formas de violência contra a mulher no romance Paraíso (2014), da escritora brasileira Tatiana Salem Levy. Busca-se compreender e problematizar a representação da dor do outro e do posicionamento das mulheres diante de situações de violência no romance. Além disso, pretende-se observar se a representação da violência sofrida pelas personagens, tanto no espaço público quanto no espaço doméstico, 
contribui para uma crítica à violência contra a mulher, desconstruindo estereótipos de submissão e vitimização.

Palavras-chave: violência contra a mulher, estudos de gênero, representação, Tatiana Salem Levy.

\section{Paradise is not here: violence against women in Tatiana Salem Levy}

\section{Paula Queiroz Dutra}

This essay aims to analyze the representations of different forms of violence against women in the novel Paraíso (2014), by Brazilian writer Tatiana Salem levy. We intend to discuss the representation of the pain of others as well as the attitude of women suffering different forms of violence in the work of a female writer. We also intend to observe if the representation of the violence suffered by the characters, both in public and domestic spaces, contributes to a critique of violence against women, helping to deconstruct stereotypes of submission and victimization.

Keywords: violence against women, gender studies, representation, Tatiana Salem Levy.

\section{El paraíso no es aquí: la violencia contra la mujer en Tatiana Salem Levy}

\section{Paula Queiroz Dutra}

Este trabajo tiene como objetivo analizar las representaciones de las distintas formas de violencia contra la mujer en la novela Paraíso (2014), de la escritora brasileña Tatiana Salem Levy. Se busca comprender y problematizar la representación del dolor del otro y del posicionamiento de las mujeres frente a situaciones de violencia dentro de la novela. Además, se pretende observar si la representación de la violencia sufrida por los personajes femeninos, tanto en el espacio público como en el doméstico, contribuye a una crítica a la violencia contra la mujer, deconstruyendo estereotipos de sumisión y victimización.

Palabras clave: violencia contra la mujer, estudios de género, representación, Tatiana Salem Levy. 